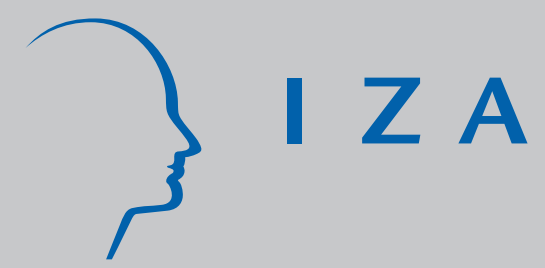

IZA DP No. 9571

Are Unemployment Rates in OECD Countries Stationary?

Evidence from Univariate and Panel Unit Root Tests

Naceur Khraief

Muhammad Shahbaz

Almas Heshmati

Muhammad Azam

December 2015 


\title{
Are Unemployment Rates in OECD Countries Stationary? Evidence from Univariate and Panel Unit Root Tests
}

\author{
Naceur Khraief \\ University of Sousse and GREDEG, University of Nice Sophia Antipolis
}

Muhammad Shahbaz

COMSATS Institute of Information Technology

Almas Heshmati

Sogang University and IZA

Muhammad Azam

Universiti Utara Malaysia

\section{Discussion Paper No. 9571 \\ December 2015}

\author{
IZA \\ P.O. Box 7240 \\ 53072 Bonn \\ Germany \\ Phone: $+49-228-3894-0$ \\ Fax: $+49-228-3894-180$ \\ E-mail: iza@iza.org
}

\begin{abstract}
Any opinions expressed here are those of the author(s) and not those of IZA. Research published in this series may include views on policy, but the institute itself takes no institutional policy positions. The IZA research network is committed to the IZA Guiding Principles of Research Integrity.

The Institute for the Study of Labor (IZA) in Bonn is a local and virtual international research center and a place of communication between science, politics and business. IZA is an independent nonprofit organization supported by Deutsche Post Foundation. The center is associated with the University of Bonn and offers a stimulating research environment through its international network, workshops and conferences, data service, project support, research visits and doctoral program. IZA engages in (i) original and internationally competitive research in all fields of labor economics, (ii) development of policy concepts, and (iii) dissemination of research results and concepts to the interested public.
\end{abstract}

IZA Discussion Papers often represent preliminary work and are circulated to encourage discussion. Citation of such a paper should account for its provisional character. A revised version may be available directly from the author. 


\section{ABSTRACT}

\section{Are Unemployment Rates in OECD Countries Stationary? Evidence from Univariate and Panel Unit Root Tests}

This paper revisits the dynamics of unemployment rate for 29 OECD countries over the period of 1980-2013. Numerous empirical studies of the dynamics of unemployment rate are carried out within a linear framework. However, unemployment rate can show nonlinear behaviour as a result of business cycles or some idiosyncratic factors specific to labour market (Cancelo, 2007). Thus, as a testing strategy we first perform Harvey et al. (2008) linearity unit root test and then apply the newly ESTAR nonlinear unit root test suggested by Kruse (2011). This test has higher power than conventional unit root tests when time series exhibits nonlinear behaviour. Our empirical findings provide significant evidence in favour of unemployment rate stationarity for 25 countries. For robustness purpose, we have also used panel unit root tests without and with structural breaks. The results show that unemployment hysteresis hypothesis is strongly rejected when taking into account the cross-sectional and structural break assumptions. Thus, unemployment rates are expected to return back to their natural levels without executing any costly macroeconomic labour market policies by the OECD's governments.

JEL Classification: $\quad$ C23, E24, J48, J64, N30

Keywords: unemployment, unit root, labour market policy, OECD

Corresponding author:

Almas Heshmati

Department of Economics

Sogang University

Baekbeom-ro (Sinsu-dong \#1), Mapo-gu

Seoul 121-742

Republic of Korea

E-mail: almas.heshmati@gmail.com 


\section{Introduction}

The empirical investigation of hypothesis of hysteresis in unemployment rate is the bone of great attention among academicians, policy makers and practitioners. The hypothesis is related to the relationship between changes in unemployment and its effect on the equilibrium level of unemployment. There are two economic theories providing theoretical and empirical discussions on unemployment behaviour. For example, hysteresis in unemployment hypothesis developed by Blanchard and Summers (1986a) reveal that any changes in actual unemployment will have permanent effect on the equilibrium level of unemployment i.e. unemployment rate contains random walk process (Furuoka, 2014) ${ }^{1}$. In such situation, equilibrium unemployment rate depends on the path and actual unemployment rate that moves around equilibrium path slowly (Blanchard and Summers, 1986b). Secondly, it is argued by Phelps (1967) and Friedman (1968) that technological development, monetary policy changes, human resource development, and macroeconomic changes in an economy affect unemployment but keep the actual unemployment rate around equilibrium level of unemployment. This shows that unemployment rate contains a stationary process which indicates that equilibrium level of unemployment is determined by actual unemployment rate in previous periods (Blanchard and Summers, 1986a).

There is another concept termed as "persistence" in unemployment rate. A primary difference between hysteresis and persistence in unemployment rate reveals that slow speed of adjustment process towards long-run equilibrium path indicates the mean reversion of unemployment series after all. It is also called a special case of nonaccelerating rate of unemployment (NAIRU). This slow speed of adjustment towards long-run equilibrium unemployment is due to introduction of wage-rigidity via efficiency wage as well as union behaviour models (Tiwari, 2014). Statistically, it is termed as near non-stationary process and in such situation, macroeconomic policy will have temporary effects on unemployment and the effects on unemployment are permanent if hysteresis hypothesis applies (Tiwari, 2014). Using time series data, Brunello (1990) for Japan, Mitchell (1993) and Røed (1996) for OECD countries, Figueiredo (2010) for Brazil, and

${ }^{1}$ This hypothesis got empirical popularity due to high unemployment rate in Europe during 1980s. 
Furuoka (2014) for South Korea accepted the presence of hysteresis unemployment hypothesis. On contrarily, rejection of hysteresis unemployment hypothesis is also validated using panel data by Camarero and Tamarit (2004) and Ener and Arica (2011) for OECD countries, Chang et al. (2005) for Central and Eastern Europe, and Lee et al. (2010) for East Asian countries, etc ${ }^{2}$.

The main purpose of this paper is to re-examine the dynamics of unemployment rate for 29 countries from OECD over the period between 1980 and 2013. The outcomes are expected to guide the policy makers of OECD countries whether they should avoid to execute or pursue costly macroeconomic stabilization polices. This paper contributes to the existing applied economics literature by five folds: (i) This paper revisits the dynamics of unemployment rates for OECD countries by applying Harvey et al. (2008) linearity test, (ii) The ESTAR nonlinear unit root test developed by Kruse (2011) is employed for testing the unit root properties of unemployment rate, (iii) The robustness of unit root analysis is tested by Lee and Strazicich (2003) unit root test with single and double unknown structural breaks, (iv) The cross-sectional dependence as well as panel unit root tests have been applied for testing either unemployment rate contains random walk process or not in the panel, and (v) The robustness of panel unit root analysis is validated by applying panel unit root by accommodating structural breaks. Our results show that the unemployment hysteresis hypothesis is rejected and unemployment rate contains stationary process.

Rest of the study is organized as follows. Section II reviews the literature on unemployment stationarity. Section III presents the econometric methodologies used. The data and empirical results are discussed in Section IV. The final Section V provides summary of the results and policy recommendations.

\section{Literature Review}

Numerous studies investigated the unit root properties of unemployment in case of OECD countries. Availability of data and rich labour market policies explains the large

\footnotetext{
${ }^{2}$ Yoon (2009) showed the presence of linearity in the US unemployment rate.
} 
number OECD based studies. For example, Mitchell (1993) started the empirical discussion for testing unit root properties of unemployment rate by applying the Perron's (1989) unit root test. The empirical results confirmed the presence of unemployment hysteresis hypothesis in OECD labour market ${ }^{3}$. Røed (1996) used data of 16 OECD countries for testing the presence of unemployment hysteresis hypothesis and found that unemployment hysteresis hypothesis is strongly confirmed in Australia but rejected in the $\mathrm{USA}^{4}$. Song and $\mathrm{Wu}(1998)$ applied the ADF and PP unit root tests to re-examine the stationary properties of unemployment rate using data of 15 OECD countries. They found that unemployment rate contains unit root problem which forces to reject the hypothesis of unemployment hysteresis. Arestis and Mariscal (1999) employed the Clemente et al. (1998) unit root test by accommodating the single and double unknown structural breaks in the series. They found that unemployment rate contains stationary process at level in the presence of structural breaks. This favours to reject the hypothesis of unemployment hysteresis ${ }^{5}$. Later on, Arestis and Mariscal (2000) applied Perron's (1997) unit root test and rejected the hypothesis of unemployment hysteresis ${ }^{6}$. Everaet (2001) also used the ADF and KPSS unit root tests to corroborate the existence of unemployment hysteresis hypothesis in OECD countries and found that unemployment rate is stationary process but contains unit root problem in the presence of infrequent level-shifts. Camarero and Tamarit (2004) tested the validation of the unemployment hysteresis hypothesis in 19 OECD countries. They applied SURADF panel unit root test and found that unemployment hysteresis hypothesis is present in 7 out of 19 countries. Camarero et al. (2006) revisited the unit root properties of unemployment rate in 19 OECD countries by applying the unit root tests with and without structural breaks. They found that in the presence of cross-dependence and structural breaks, unemployment hysteresis hypothesis is rejected which implies that shock affects unemployment rate but temporarily.

Yilanci (2008) applied the linear and non-linear unit root tests developed by Kapetanios et al. (2003) to examine the stationary properties of unemployment in 17 OECD

\footnotetext{
${ }^{3}$ Elmskov and MacFarlan (1993) also presented the channels comprehensively on how labor markets are affected by macroeconomic shocks.

${ }^{4}$ Røed (2002) confirmed the presence of unemployment hysteresis in 10 OECD countries.

${ }^{5}$ Fève et al. (1999) also validated the presence of wage hysteresis for OECD countries.

${ }^{6}$ Australia, Belgium, Canada, Denmark, Finland, Germany, Luxemburg, Switzerland and the UK.
} 
countries. The results of ADF unit root test leads to accept the hypothesis of unemployment hysteresis i.e. unemployment contains random walk process. After knowing the presence of non-linearity in unemployment, KSS unit root test is employed and found that results support to accept unemployment hysteresis hypothesis. This concludes that unemployment rate contains unit root process. Lee and Chang (2008) applied the LM unit root test developed by Lee and Strazicich (2004) to examine the presence of unemployment hysteresis hypothesis in 14 major OECD countries. The minimum LM unit root test is found suitable for investigating the unit root properties of unemployment in the presence of single unknown structural break in the series. Their results indicated that unemployment rate is stationary at level in the presence of single unknown structural break. This indicates the rejection of unemployment hysteresis hypothesis i.e. economic shocks have permanent effect on labour markets in OECD countries. Lee et al. (2009) tested the validation of hypothesis of unemployment hysteresis by applying the LM unit root test in the presence of heterogeneous structural breaks developed by Im et al. (2005). Their empirical evidence favours to reject the hypothesis of unemployment hysteresis and indicates that economic shocks occurring in labour market have temporary impact on unemployment rates in OECD countries. Lee, (2010) used the nonlinear heterogeneous panels to re-examine the unit root properties of unemployment rate in 29 OECD countries. The nonlinear unit root test developed by Ucar and Omay (2009) is applied for empirical purpose. The empirical results show that null hypothesis of unemployment rate hysteresis is rejected which indicates that unemployment rate contains stationary process at level.

Fosten and Ghashray (2011) used the regime switching unit root test developed by Leybourne et al. (2007) in examining the unit root properties of unemployment rate in OECD countries ${ }^{7}$. Leybourne et al. (2007) argued that regime switching such as World War I and Great Depression may cause of unit root problem in unemployment rates. Based on the empirical analysis, Fosten and Ghashray (2011) noted that hypothesis of unemployment hysteresis is validated after World War I and Great Depression due to

\footnotetext{
${ }^{7}$ Chang and Lee (2011) applied the threshold unit root test developed by Caner and Hansen (2001) to revisit the hypothesis of unemployment hysteresis in case of Canada, France, Germany, Italy, Japan, UK and US. They found that hysteresis in unemployment is present for France, Germany and Italy.
} 
strong labour unions corroborating the findings of Blanchard and Summers (1986b). Huang (2011) employed the Nybolm and Harvey (2000) unit root test to re-examine the presence of "hysteresis in unemployment". His findings indicate the presence of nonstationarity in OECD countries i.e. validating the presence of hypothesis of unemployment hysteresis.

Liew et al. (2012) revisited the unemployment hysteresis hypothesis by applying parametric and non-parametric panel unit root tests in OECD countries. Their empirical evidence is in favour of accepting the unemployment hysteresis hypothesis in most of the OECD countries once country-level analysis is conducted ${ }^{8}$. They argued that crosscountry labour market independence should be incorporated while testing the unemployment hysteresis hypothesis. Using panel unit root tests, they found the rejection of the unemployment hysteresis hypothesis in OECD countries. This shows that labour market institutions as well as stabilization in economic policies have played their important role to maintain unemployment at sustainable level in OECD countries. The quintile unit root test developed by Galvao (2009) is applied by Lee et al. (2013) to validate the hypothesis of unemployment hysteresis after knowing about asymmetries in unemployment rate in OECD countries. They exposed that unemployment rate contains stationary process. Using data of PIIGS (Portugal, Ireland, Italy, Greece and Spain), Cheng et al. (2014) tested the stationary properties of unemployment rates by applying Flexible Fourier unit root test developed by Enders and Lee (2012). Their results favoured to accept the hypothesis of "hysteresis in unemployment"9. A summary of the different test results found in the literature is presented in Appendix A.

\footnotetext{
${ }^{8}$ Using state-level data, Liu et al. (2012) reported that unemployment hysteresis hypothesis is accepted in Australia.

${ }^{9}$ Furuoka (2014) examined whether hypothesis of hysteresis in unemployment exists or not in case of AsiaPacific countries by applying Fourier ADF unit root test. The empirical results indicated that unemployment rate contains stationary process for South Korea, Australia and Hong Kong but in China and Japan unemployment rate contains unit root problem.
} 


\section{III.Econometric Methodologies}

This section presents econometric methodologies used involving individual and panel unit root tests. The first group include weighted tests for linearity/non-linearity applied to processes of different integration orders with structural breaks and functional forms. The second group include the first and second generations of panel unit root tests aimed at increasing the power of the univariate unit root tests. They differ by their treatment of cross-sectional dependency and ignore presence of structural breaks. This is accounted for in several augmented alternative tests.

\section{III.I Individual unit root tests}

Prior to the application of individual unit root tests, we begin by testing the null hypothesis of linearity against a nonlinear alternative. The linearity test can be applied to decide which of the unit root tests (linear or nonlinear) should be employed to check if the series is stationary. We utilize a recently introduced linearity test proposed by Harvey et al. (2008) which can be applied either to I(0) or I(1) processes. Moreover, when the order of integration is unknown, this test has superior finite sample size and power proprieties to Harvey and Leybourne (2007) linearity test. If the integration of series is unknown, Harvey et al. (2008) suggest constructing a weighted average Wald test statistic which can be written as follows:

$$
W_{\lambda}=(1-\lambda) W_{0}+\lambda W_{1} \underset{d}{\rightarrow} \chi^{2}(2)
$$

where $W_{0}$ and $W_{1}$ denote the Wald tests when the variable is $\mathrm{I}(0)$ and $\mathrm{I}(1)$, respectively. Both tests follow the standard $\chi^{2}(2)$ distribution. $\lambda$ is a some function that converges in probability to 1 when the variable is $\mathrm{I}(1)$ and to 0 when the process is $\mathrm{I}(0)$. According to Harvey et al. (2008), a suitable function must be chosen for $\lambda$. Thus, the authors suggested the following functional form:

$$
\lambda(U, S)=\exp \left(-g\left(\frac{U}{S}\right)^{2}\right)
$$


where $g$ is some finite positive constant which has no effect on the asymptotic proprieties of $W_{\lambda} . U$ and $S$ denote appropriately chosen unit root and stationarity statistics. Harvey et al. (2008) propose to use the standard Dickey-Fuller unit root statistic for $U$ and the nonparametric stationarity statistic of Harris et al. (2003) for $S$. When the time series is stationary, $\left(\frac{U}{S}\right)^{2}$ diverges and $\lambda$ converges to zero, and when the time series is unit root, $\left(\frac{U}{S}\right)^{2}$ converges to zero resulting in $\lambda$ converging to 1 .

When the data generating process exhibit non-linearity, the linear unit root tests (ADF, Phillips-Perron and KPSS) may not possess good power, i.e. they tend to over accept the unit root null hypothesis. To address this concern, we perform the nonlinear unit root test recently developed by Kruse (2011). This test is based on the Kapetanios et al. (2003) approach for testing the unit root hypothesis against the alternative of a globally stationary exponential smooth transition autoregression (ESTAR) model:

$$
y_{t}=\beta y_{t-1}+\emptyset y_{t-1} F\left(\theta ; y_{t-1}\right)+\varepsilon_{t}
$$

where $\varepsilon_{t}$ is $\operatorname{iid}\left(0, \sigma^{2}\right)$ and $F\left(\theta ; y_{t-1}\right)$ is the transition function which has an exponential form:

$$
F\left(\theta ; y_{t-1}\right)=1-\exp \left\{-\theta\left(y_{t-1}-c\right)^{2}\right\}
$$

with $\theta \geq 0$. The transition function, which exists between zero and one, is symmetrically U-shaped around zero. Kapetanios et al. (2003) show that the ESTAR model, under the restriction $\beta=0$, is globally stationary if $-2<\emptyset<0$ is satisfied even though it is locally nonstationary in $y_{t-1}=c$. The authors assume that $c=0$ and propose the following model:

$$
\Delta y_{t}=\beta y_{t-1}+\emptyset y_{t-1}\left(1-\exp \left\{-\theta y_{t-1}^{2}\right\}\right)+\varepsilon_{t}
$$

In order to test the null hypothesis $H_{0}: \theta=0$ versus the alternative $H_{1}: \theta>0$, Kapetanios et al. (2003) impose the restriction $\beta=0$. By applying a first-order Taylor approximation to the ESTAR model, around $\theta=0$, an auxiliary regression can be obtained:

$$
\Delta y_{t}=\delta_{1} y_{t-1}^{3}+\mu_{t}
$$


with $\mu_{t}$ being a noise term depending on $\varepsilon_{t}, \emptyset$ and the rest of the Taylor expansion. Kapetanios et al. (2003) suggested a Dickey-Fuller type $t$ test, denoted as KSS, for unit root null hypothesis against globally stationary ESTAR which correspond to $E_{0}: \tilde{\delta}_{1}=0$ against the alternative $H_{1}: \delta_{1}<0$ :

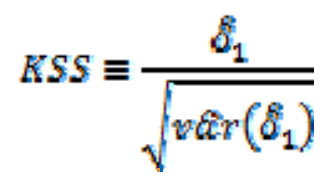

Kruse (2011) suggested that the zero location parameter $c$ in the exponential transition function is too restrictive. Therefore, the author propose an extension of Kapetanios et al. (2003) unit root test by relaxing the zero restriction on c and considers the following modified ADF regression:

$$
y_{t}=\beta y_{t-1}+\varnothing y_{t-1}\left(1-\exp \left\{-\Theta\left(y_{t-1}-\epsilon\right)^{2}\right\}\right)+s_{t}
$$

By applying the first-order Taylor approximation of the smooth transition function around $\theta=0$, the regression model is written as follows:

$$
\Delta y_{t}=\delta_{1} y_{t-1}^{a}+\delta_{2} y_{t-1}^{2}+\delta_{a} y_{t-1}+\mu_{t}
$$

In order to improve the power of test, Kruse (2011) imposes $\delta_{\mathrm{a}}=0$ and proceeds with:

$$
\Delta y_{t}=\delta_{1} y_{t-1}^{a}+\delta_{2} y_{t-1}^{2}+\mu t_{t}
$$

where $\delta_{1}=\theta \emptyset$ and $\delta_{2}=-2 c \theta \emptyset$. The null hypothesis $H_{0}: \delta_{1}=\delta_{2}=0$ is tested against the alternative $H_{1}: \delta_{1}<0_{n} \delta_{2} \neq 0$. Kruse, (2011) suggested to employ the methods of Abadir and Distaso (2007) to derive a modify Wald test. This modified Wald test builds upon the one-sided parameter $\left(\delta_{1}\right)$ and the transformed two-sided parameter, say $8 \frac{1}{2}$, that are stochastically independent by definition.

Regarding the series that exhibits linear behaviour, we employ the LM unit root tests with structural breaks developed by Lee and Strazicich (2003). They suggested the following Data Generating Process (DGP): 


$$
y_{t}=\delta^{\prime} Z_{t}+e_{t}, e_{t}=\beta e_{t-1}+\varepsilon_{t}
$$

And they defined the structural breaks models $\mathrm{C}$ and $\mathrm{CC}$ as follows:

1) The Model $\mathrm{C}$ which can be described by $Z_{t}=\left[1, t, D_{t}, D T_{t}\right]$ where $D T_{t}=t-T B_{t}$ for $t \succ T_{B}+1$, zero otherwise.

2) The Model CC that contains two changes in level and trend is described by $Z_{t}=\left[1, t, D_{1 t}, D_{2 t}, D T_{1 t}, D T_{2 t}\right]$ where $D T_{j t}=t-T B_{j t}$ for $t \succ T_{B}+1, j=1,2$, zero otherwise.

The LM unit root test statistic can be estimated by regression according to the LM (score) principle as follows:

$$
\Delta y_{t}=\delta^{\prime} \Delta Z_{t}+\phi \widetilde{S}_{t-1}+u_{t}
$$

where $\widetilde{S}_{t-1}=y_{t}-\widetilde{\psi}_{x}-Z_{t} \widetilde{\delta}, t=2, \ldots, T, \widetilde{\delta}$ are coefficients in the regression of $\Delta y_{t}$ on $\Delta Z_{t}$, $\widetilde{\psi}_{x}$ is given by $y_{1}-Z_{1} \widetilde{\delta}$. The unit root null hypothesis is described by $\phi=0$ and the LM test statistics are given by:

$$
\widetilde{\rho}=T . \widetilde{\phi}
$$

$\tilde{\tau}=\mathrm{t}$-statistic testing null hypothesis $\phi=0$.

The minimum LM unit root test determines the break points $T B_{j t}$ endogenously by using a grid search as follows:

$$
\begin{aligned}
& L M_{\rho}=\operatorname{Inf}_{\lambda} \widetilde{\rho}(\lambda) \\
& L M_{\tau}=\operatorname{Inf}_{\lambda} \widetilde{\tau}(\lambda)
\end{aligned}
$$

where $\lambda=T_{B} / T$. The break points are determined to be where the test statistic is minimized. In order to eliminate the end points, we use the trimming region $(0.15 T, 0.85 T)$, where $T$ is a sample size. The critical values for one break and two breaks are given by Lee and Strazicich (2003, 2013). 


\section{III.II Panel unit root tests}

In order to increase power of univariate unit root test, we also use panel unit root tests. Which are separated into "first generation panel unit root tests" including LLC test (Levin et al., 2002), IPS test (Im et al., 2003), MW test (Maddala and Wu, 1999) and Choi test (Choi, 2001) and the "second generation panel unit root tests" containing MP test (Moon and Perron, 2004), Pesaran test (Pesaran, 2007) and Choi test (Choi, 2006). First generation tests do not allow for cross-sectional dependence between units; however, second generation tests take into account the cross sectional dependency. The first and second generation tests which do not allow for the structural breaks may suffer from significant loss of power if data display possible breaks. This is why we suggest using Lagrange Multiplier (LM) panel unit root test developed by Im, Lee and Tieslau (2005). The LLC test (Levin et al., 2002), which allows for homogeneity of the first order autoregressive parameters and the cross sectional independence between units, suggests the following adjusted $t$ statistic:

$$
t_{\rho}^{*}=\frac{t_{\rho}}{\sigma_{T}^{*}}-N T \hat{S}_{N}\left(\frac{\hat{\sigma}_{\hat{\rho}}}{\hat{\sigma}_{\hat{\varepsilon}}^{2}}\right)\left(\frac{\mu_{T}^{*}}{\sigma_{T}^{*}}\right)
$$

where $\hat{S}_{N}$ denotes the average of individual ratios of long-run towards short-run variances for individual $i . \hat{\sigma}_{\hat{\rho}}$ and $\hat{\sigma}_{\hat{\varepsilon}}^{2}$ are respectively the standards deviations of slope coefficients and error term. The mean adjustment $\mu_{T}^{*}$ and standard deviation adjustment $\sigma_{T}^{*}$ are tabulated by Levin, Lin, and Chu (2002, p. 14) for various periods $T$.

The IPS (Im, Pesaran and Shin, 2003) test which assumes heterogeneity of the first order autoregressive parameters employs a standardized t_bar statistic based on the limiting distribution of individual ADF statistics:

$$
Z_{\text {tbar }}(p ; \beta)=\frac{\sqrt{N}\left[t_{-} b a r_{N T}-E\left(t_{i T}\right)\right]}{\sqrt{V\left(t_{i T}\right)}}
$$


where $E\left(t_{i T}\right)$ and $V\left(t_{i T}\right)$ are respectively the expected mean and variance of $t_{i T}$ (the $t$ statistic).

The MW test (Maddala and Wu, 1999) which uses Fisher type test (1932) is based on combined p-values $p_{i}$ or $P_{M W}$, from unit root test-statistics for each cross-sectional unit $i$. The MW test (Maddala and $\mathrm{Wu}, 1999)$ proposed the statistics as: $P_{M W}=-2 \sum_{i=1}^{N} \ln \left(p_{i}\right)$ which has a $\chi^{2}$ distribution with $2 N$ degrees of freedom as $T \rightarrow \infty$ and $N$ fixed. This test was suggested by Fisher (1932). In addition, Choi (2006) suggested the following standardized statistic:

$$
M W=\frac{\sqrt{N}\left\{N^{-1} P_{M W}-E\left[-2 \ln \left(p_{i}\right)\right]\right\}}{\sqrt{V\left[-2 \ln \left(p_{i}\right)\right]}} .
$$

Under the null hypothesis as $T_{i} \rightarrow \infty$ and $T \rightarrow \infty, Z_{M W} \rightarrow N(0,1)$ (Hurlin, 2004). Concerning second-generation unit root tests, which assume cross sectional dependence between units, we used MP test (Moon and Perron, 2004), Pesaran test (Pesaran, 2007) and Choi test (Choi, 2006). Further, to take into account cross-sectional dependence assumption, Moon and Perron (2004) use an AR(1) model with common factors in error terms:

$$
\begin{aligned}
& y_{i, t}=\left(1-\lambda_{i}\right) \mu_{i}+\lambda_{i} y_{i, t}+u_{i, t} \\
& u_{i, t}=\delta_{i}^{\prime} F_{t}+e_{i, t} .
\end{aligned}
$$

For $i=1, \ldots, N$ and $t=1, \ldots, T . F_{t}$ is a $(k \times 1)$ vector of commons factors, $\delta_{i}$ is the coefficients vector corresponding to the common factors and $e_{i, t}$ is an idiosyncratic error term which is cross-sectionally uncorrelated and follows an infinite Moving Average (MA) process. The null hypothesis corresponds to the unit root hypothesis $\mathrm{H}_{0}: \lambda_{i}=1$ for $i=1, \ldots, N$ against the heterogeneous alternative hypothesis $\mathrm{H}_{1}: \lambda_{i}<1$ for some $i$. For testing, the data are de-factored and then the panel unit root test statistics based on defactored data are proposed. 
To construct a unit root test, Moon and Perron (2004) considered the factors as nuisance parameters and developed two t-statistics, which are based on a pooled de-factored series. Specifically, if we let $\hat{\lambda}^{*}$ denote pooled least squares estimate of $\lambda$ using the de-factored data, Moon and Perron (2004) suggest that the following two statistics can be used:

$$
\begin{aligned}
t_{a}^{*} & =\frac{\sqrt{N} T\left(\hat{\lambda}^{*}-1\right)}{\sqrt{\frac{2 \hat{\varphi}_{e}^{4}}{\hat{\omega}_{e}^{4}}}} \underset{T, N \rightarrow \infty}{\longrightarrow} N(0,1) \\
t_{b}^{*} & =\sqrt{N} T\left(\hat{\lambda}^{*}-1\right) \sqrt{\frac{1}{N T^{2}} \operatorname{tr}\left(Y_{t-1} Q_{\hat{\Delta}} Y_{t-1}^{\prime}\right)}\left(\frac{\hat{\omega}_{e}}{\hat{\varphi}_{e}^{2}}\right) \underset{T, N \rightarrow \infty}{\longrightarrow} N(0,1)
\end{aligned}
$$

where $\hat{\varphi}_{e}^{4}$ denotes cross-sectional average of $\hat{\omega}_{e}^{4}$. The statistics $t_{\alpha}^{*}$ and $t_{b}^{*}$ are based on an estimator of projection matrix and estimators of long-run variances $\hat{\varphi}_{e}^{2}$. In Pesaran's test (2007), the author suggests to augment the cross-sectional unit $A D F\left(p_{i}\right)$ regressions by cross-sectional means of lagged levels and first-differences of the individual time series. The cross-sectionally augmented $A D F$ regressions are given by:

$$
\Delta y_{i, t}=\alpha_{i}+\rho_{i} y_{i, t-1}+c_{i}\left[(1 / N) \sum_{i=1}^{N} y_{i, t-1}\right]+d_{i}\left[(1 / N) \sum_{i=1}^{N} \Delta y_{i, t}\right]+\varepsilon_{i, t}
$$

Pesaran (2007) suggested the following truncated test statistics which is denoted as a Cross-Sectional Augmented IPS (CIPS):

$$
\operatorname{CIPS}(N, T)=\frac{1}{N} \sum_{i=1}^{N} t_{i}(N, T)
$$

where $t_{i}(N, T)$ the $\mathrm{t}$-statistic of the OLS estimates of is $\rho_{i}$ (denoted as CADF). The Pesaran test statistic is the modified IPS statistics based on average of individual CADF. The next panel unit root test is the Choi, (2006) test which combines p-values of Augmented Dickey-Fuller univariate tests. In first step, the panel unit root tests of Choi, (2006) use Elliott et al. (1996) GLS de-trending, to eliminate the cross-sectional 
correlations and controlling for the deterministic trends. In second step, meta-analytic panel tests are used. Choi (2006) assumes the following two-way error-component model:

$$
\begin{aligned}
& y_{i, t}=\alpha_{i}+\theta_{t}+u_{i, t} \\
& u_{i, t}=\sum_{j=1}^{p_{i}} d_{i, j} u_{i, t-1}+\varepsilon_{i, t}
\end{aligned}
$$

where $\varepsilon_{i, t}$ isi.i.d $\left(0, \sigma_{\varepsilon_{i}}^{2}\right)$. Then, after having obtained the p-values of t-statistics, Choi (2006) combined these into panel test (Fisher's type) statistics as follows:

$$
\begin{aligned}
& P_{m}=-\frac{1}{\sqrt{N}} \sum_{i=1}^{N}\left[\ln \left(p_{i}\right)+1\right] \underset{T, N \rightarrow \infty}{\longrightarrow} N(0,1) \\
& Z=-\frac{1}{\sqrt{N}} \sum_{i=1}^{N} \phi^{-1}\left(p_{i}\right) \underset{T, N \rightarrow \infty}{\longrightarrow} N(0,1) \\
& L^{*}=-\frac{1}{\sqrt{\pi^{2} N / 3}} \sum_{i=1}^{N} N \ln \left(\frac{p_{i}}{1-p_{i}}\right) \underset{T, N \rightarrow \infty}{\longrightarrow} N(0,1)
\end{aligned}
$$

where $\phi$ is the standard cumulative normal distribution function and $p_{i}$ is the asymptotic p-values of the Dickey-Fuller-GLS statistic for country $i$.

The first and second generation tests don't allow for structural breaks and may suffer from significant loss of power if data display possible breaks. This is why we suggest using Lagrange Multiplier (LM) panel unit root test developed by Im, Lee and Tieslau (2005). Based on univariate LM statistic (Lee and Strazicich, 2003), Im, Lee and Tieslau (2005) suggested a panel LM t-statistic. Lee and Strazicich's model can be recalled as follows:

$$
\Delta Y_{i, t}=\gamma_{i}^{\prime} \Delta Z_{i, t}+\delta_{i} \hat{S}_{i, t-1}+\varepsilon_{i, t}
$$


where, $\Delta$ is the first difference operator, $\hat{S}_{i, t-1}$ is detrended variable of $Y_{i, t-1}$ and $\varepsilon_{i, t}$ denotes error term. The t-statistic (denoted $t^{*}$ ) for the null hypothesis $H_{0}: \delta_{i}=0$ can be calculated for each unit in order to compute LM test statistic:

$$
\bar{t}=\frac{1}{N} \sum_{i=1}^{N} t_{i}^{*}
$$

This in turn can be used to determine the following standardized panel LM test statistic:

$$
L M(\bar{t})=\frac{\sqrt{N}(\bar{t}-E(\bar{t}))}{\sqrt{V(\bar{t})}}
$$

Where $E(\bar{t})$ and $V(\bar{t})$ are tabulated by $\operatorname{Im}$, Lee and Tieslau (2005).

\section{IV.Data and Empirical Results}

The World Economic Outlook database (International Monetary Fund, April 2014) was the source of data on the unemployment rates in 29 OECD countries over the period 1980-2013 and summary statistics of the data are reported (see Appendix). Spain and Switzerland have the highest and the lowest average employment rates, respectively. The unemployment rate tends to be more volatile for Ireland and Spain. Jarque-Bera statistics indicate that we reject the null hypothesis of normal distribution for Chile, Greece, Korea, Iceland Portugal and Turkey. This result is consistent with Skewness and Kurtosis statistics.

The issue being investigated is whether unemployment rate in OECD countries contains a unit root. Our empirical analysis begins by conducting the nonlinearity of time series in order to decide which unit root test we should run. If the time series were to follow a nonlinear path over time, the standards unit root tests become powerless by over accepting the null hypothesis (Kapetanios et al. 2003; Kruse, 2011). To test the null hypothesis of linearity against the alternative nonlinear model we use the Harvey et al. (2008) test. This test has better size control and offers substantial power gains over Harvey and Leybourne 
(2007) linearity test. When the linearity hypothesis is rejected, we apply the Kruse, (2001) nonlinear unit root test, which is an extension of Kapetanios et al. (KSS, 2003) one. This test has a main advantage that it improves the power and size of KSS test by relaxing the assumption of a zero location parameter in the smooth transition function.

Table 1: Linearity Test Results

\begin{tabular}{|l|c|c|c|}
\hline Countries & Statistics & Prob. value & Result \\
\hline Australia & 7.616 & 0.107 & Linear \\
\hline Austria & 2.718 & 0.606 & Linear \\
\hline Belgium & 11.242 & 0.024 & Non Linear \\
\hline Canada & 1.753 & 0.781 & Linear \\
\hline Chile & 2.709 & 0.608 & Linear \\
\hline Denmark & 10.248 & 0.036 & Non Linear \\
\hline Finland & 6.538 & 0.162 & Linear \\
\hline France & 2.264 & 0.687 & Linear \\
\hline Germany & 3.515 & 0.476 & Linear \\
\hline Greece & 13.715 & 0.008 & Non Linear \\
\hline Hungary & 13.893 & 0.008 & Non Linear \\
\hline Iceland & 4.991 & 0.288 & Linear \\
\hline Ireland & 0.553 & 0.968 & Linear \\
\hline Israel & 0.766 & 0.943 & Linear \\
\hline Italy & 0.600 & 0.963 & Linear \\
\hline Japan & 14.217 & 0.007 & Non Linear \\
\hline Korea & 6.533 & 0.163 & Linear \\
\hline Luxembourg & 2.881 & 0.578 & Linear \\
\hline Mexico & 22.893 & 0.000 & Non Linear \\
\hline Netherlands & 3.648 & 0.456 & Linear \\
\hline New Zealand & 2.203 & 0.699 & Linear \\
\hline Norway & 3.181 & 0.528 & Linear \\
\hline Portugal & 1.162 & 0.884 & Linear \\
\hline Spain & 12.887 & 0.012 & Non Linear \\
\hline Sweden & 8.454 & 0.076 & Non Linear \\
\hline Switzerland & 15.112 & 0.004 & Non Linear \\
\hline Turkey & 18.879 & 0.001 & Non Linear \\
\hline United Kingdom & 1.830 & 0.767 & Non Linear \\
\hline United States & 11.142 & 0.025 & \\
\hline Note: The 1\%, 5\%, and $10 \%$ critical values for Harvey et al. $(2008)$ test & & are respectively 7.779, \\
9.488, and 13.277. & & & \\
\hline & & & \\
\hline
\end{tabular}


The result presented in Table 1 here show that the null hypothesis of linearity is rejected in 11 cases out of 29 OECD countries. Our finding is an interesting contrast to those in previous empirical studies that used the conventional linear unit root tests (see Cross, 1995; Neudorfer et al., 1990; and Røed 2002). We have carried out the Kruse (2011) test along with LM univariate linear unit root tests. When the linearity hypothesis is rejected, results from Kruse (2011) test of Table 2 provideno evidence for the hysteresis of the unemployment rates in Belgium, Denmark, Greece, Mexico, Switzerland, Turkey and United States. This indicates that unemployment rate contains stationarity process and transitory shocks to the unemployment rate have temporary effects in these economies.

Table 2: ESTAR Unit Root Test Results

\begin{tabular}{|l|c|c|}
\hline Countries & KSS & Result \\
\hline Belgium & -3.349 & Stationary \\
\hline Denmark & -4.294 & Stationary \\
\hline Greece & -3.111 & Stationary \\
\hline Hungary & -1.262 & Non stationary \\
\hline Japan & -2.417 & Non stationary \\
\hline Mexico & -7.536 & Stationary \\
\hline Spain & -2.316 & Non stationary \\
\hline Sweden & -2.367 & Non stationary \\
\hline Switzerland & -2.919 & Stationary \\
\hline Turkey & -3.554 & Stationary \\
\hline United States & -3.589 & Stationary \\
\hline $\begin{array}{l}\text { Note: The } 1 \%, 5 \%, \text { and } 10 \% \text { critical values, for Kruse (2011) test, are } \\
\text { respectively }-3.48,-2.93, \text { and }-2.66 .\end{array}$ \\
\hline
\end{tabular}

However, in Hungary, Japan, Spain and Sweden, the nonlinear unit root test rejects stationarity process which supports the strong evidence in favour of the hysteresis hypothesis. When we consider the LM unit root test with structural breaks, the unit root null hypothesis is rejected for all 18 countries that exhibit linear behaviour (Table 3), and then any shock to unemployment rate is likely to be transitory. These results support therefore natural rate hypothesis when structural break dummies are included in regressions. The LM unit root tests result showed that there are two significant break dates in the selected countries that exhibit linear behaviour. 
Table 3: LM Univariate Unit Root Test Results

\begin{tabular}{|c|c|c|c|c|c|c|c|c|c|c|}
\hline Country & $\begin{array}{l}\text { LM univariate test without } \\
\text { break } \\
\text { (Schmidt and Phillips, } \\
\text { 1992) }\end{array}$ & $k$ & $\begin{array}{c}\text { LM univariate test with one } \\
\text { break } \\
\text { (Model C) }\end{array}$ & $k$ & $T B$ & $\begin{array}{c}\text { LM univariate test with two } \\
\text { breaks } \\
\text { (Model CC) }\end{array}$ & $k$ & $T B_{4}^{2}$ & $T E_{g}$ & Result \\
\hline Australia & $-0.1608 \quad(-2.0080)$ & 1 & $-0.5450 * * * \quad(-4.4502)$ & 1 & 1996 & $-1.2804 * * * \quad(-5.4236)$ & 4 & 1997 & 2008 & Stationary with break \\
\hline Austria & $(-2.7599)$ & 0 & $-0.4752 * \quad(-3.3904)$ & 0 & 1998 & $-1.1835 * * * \quad(-5.6526)$ & 3 & 1986 & 1994 & Stationary with break \\
\hline Canada & $-0.2219 \quad(-2.6791)$ & 1 & $-0.4593 * * * \quad(-4.2837)$ & 1 & 1996 & $-0.4436 * * * \quad(-5.2417)$ & 1 & 1996 & 2008 & Stationary with break \\
\hline Chile & $-0.3246 * *(-3.2517)$ & 0 & $-0.4351 * * * \quad(-4.6163)$ & 0 & 1998 & $-0.4886 * * * \quad(-5.2052)$ & 3 & 1998 & 2008 & Stationary \\
\hline Finland & $-0.1774 * \quad(-2.9725)$ & 1 & $-0.4300 * * * \quad(-4.8683)$ & 1 & 1995 & $-0.8735 * * * \quad(-7.0389)$ & 1 & 1990 & 1996 & Stationary \\
\hline France & $-0.1091 \quad(-1.6721)$ & 1 & $-0.6150 * * \quad(-3.6542)$ & 3 & 1998 & $-0.6995 * * * \quad(-4.5913)$ & 3 & 1993 & 2008 & Stationary with break \\
\hline Germany & $-0.2190 \quad(-2.5261)$ & 1 & $-0.6647 * *$ & 4 & 2008 & $-1.3466 * * * \quad(-6.5075)$ & 4 & 1988 & 2003 & Stationary with break \\
\hline Iceland & $-0.4303 * *(-3.1886)$ & 1 & $(-3.5281)$ & 1 & 2007 & $-1.7403 * * * \quad(-7.7935)$ & 3 & 1992 & 2007 & Stationary \\
\hline Ireland & $-0.0767 \quad(-1.9661)$ & 2 & $(-2.8126)$ & 2 & 1994 & $-1.4408 * * * \quad(-4.6883)$ & 4 & 1991 & 2001 & Stationary with break \\
\hline Israel & $(-2.0804)$ & 1 & $-0.6120 * * \quad(-3.9196)$ & 1 & 2005 & $-0.5952 * * * \quad(-4.5782)$ & 1 & 2000 & 2008 & Stationary with break \\
\hline Italy & $(-1.8946)$ & 1 & $(-3.4787)$ & 1 & 2003 & $-0.9934 * * *(-6.2593)$ & 4 & 1992 & 2004 & Stationary with break \\
\hline Korea & $(-2.0827)$ & 0 & $-0.6327 * * \quad(-3.6407)$ & 1 & 1992 & $-2.1961 * * * \quad(-9.6969)$ & 3 & 1996 & 2003 & Stationary with break \\
\hline Luxembourg & $(-2.7533)$ & 1 & $-0.4808 * * * \quad(-4.4243)$ & 2 & 2008 & $-0.5625 * * * \quad(-4.9943)$ & 2 & 2003 & 2008 & Stationary with break \\
\hline Netherlands & $(-1.8309)$ & 2 & $-0.2565 * * \quad(-3.9757)$ & 1 & 1995 & $-0.5851 * * * \quad(-6.0283)$ & 1 & 1987 & 1997 & Stationary with break \\
\hline New Zealand & $(-2.0373)$ & 1 & $-0.4627 * \quad(-3.3251)$ & 1 & 1992 & $-1.5085 * * * \quad(-8.2367)$ & 3 & 1989 & 2004 & Stationary with break \\
\hline Norway & $(-2.4340)$ & 1 & $-0.5352 * * *(-4.8938)$ & 1 & 1994 & $-0.6388 * * * \quad(-5.9534)$ & 1 & 1989 & 1995 & Stationary with break \\
\hline Portugal & $(-3.0432)$ & 2 & $-0.5970 * * *(-6.7717)$ & 2 & 2003 & $-1.0810 * * *(-11.2904)$ & 3 & 1987 & 2004 & Stationary \\
\hline United Kingdom & $(-2.5462)$ & 1 & $-0.2867 * \quad(-3.3916)$ & 1 & 1996 & $-0.7246 * * * \quad(-5.1861)$ & 3 & 1986 & 2007 & Stationary with break \\
\hline
\end{tabular}

Notes: Numbers in the parentheses are the optimal number of lagged first-differenced terms included in the unit root test to correct for serial correlation. The $1 \%, 5 \%$ and $10 \%$ critical values for the LM unit root test with no break are: $-3.63,-3.06$, and -2.77 . The $1 \%, 5 \%$, and $10 \%$ critical values for the minimum LM test with one break are: -4.239 ,

-3.566 , and -3.211 . The $1 \%, 5 \%$, and $10 \%$ critical values for the minimum LM test with two breaks are: $-4.545,-3.842$, and -3.504 , respectively. 
These dates are 1987-88, 1997-1998 and 2007-2008 which can be associated with three crisis events (Black Monday 1987, 1997 Asian Financial crisis, and 2007-2008 Global Financial crisis). Overall, our empirical findings provide significant support for unemployment rate stationarity process in 25 out of 29 countries, and therefore there is an absence of unemployment hysteresis hypothesis in these countries. Previous empirical studies have reached mixed conclusions about whether unemployment rate in OECD countries is stationary or contains unit root process. Our results are not in line with earlier findings about unemployment hysteresis in OECD countries (Brunello, 1990; Neudorfer, Pichelmann, and Wagner, 1990; Mitchell, 1993; Jaeger and Parkinson, 1994; Røed, 1996). These empirical studies did not consider nonlinearity and structural changes when testing a unit root hypothesis. However, the nonlinear behaviour of employment rate in OECD countries is recognized in the existing applied economics literature due to business cycles or some idiosyncratic factors specific to the labour market (Cancelo, 2007).

Recently, some empirical studies used nonlinear unit root test to investigate the stationarity proprieties of unemployment. Yilanci (2008) carried out the KSS test to unemployment rates in 17 OECD countries and found evidence in favour of stationarity hypothesis for only 7 countries. This study, however, does not account for possible breaks in the series of unemployment rates. Hence, compared to these studies, our empirical findings provide more obvious evidence in favour of unemployment rate stationarity among 29 OECD countries while allowing for both nonlinearity and structural breaks in series. Turning to the panel unit root tests, we begin by applying the cross-section dependence (CD) tests developed by Pesaran (2004), Friedman (1937) and Frees (1995). Table 4 indicates that null hypothesis of cross-sectional dependence is rejected for the entire panel highlighting that unemployment rate is highly dependent across OECD countries. This finding indicates the importance of taking into account cross-sectional dependence when analysing the stationarity of OECD countries panel. 
Table 4: Cross Sectional Dependence Test Results

\begin{tabular}{|l|c|}
\hline Cross sectional dependence test & Full Panel \\
\hline Frees' test of cross sectional independence (p-value) & 1.653 \\
& $(0.0000)$ \\
\hline Pesaran's test of cross sectional independence (p-value) & -0.131 \\
& $(0.1044)$ \\
\hline Friedman's test of cross sectional independence (p-value) & 52.918 \\
& $(0.0030)$ \\
\hline
\end{tabular}

Table 5: Panel Data Unit Root Results ${ }^{10}$

\begin{tabular}{|l|c|c|c|c|}
\hline \multicolumn{5}{|c|}{ First Generation of Panel Unit Root Tests: Full panel } \\
\hline Types of test statistic & Test statistic & $1 \%$ CV & $5 \%$ CV & $10 \%$ CV \\
\hline LLC test statistic & -1.1319 & -2.3263 & -1.6449 & -1.2816 \\
\hline IPS test statistic & -1.0959 & -2.3263 & -1.6449 & -1.2816 \\
\hline MW test statistic & 90.9817 & 85.9502 & 76.7778 & 72.1598 \\
\hline Choi test statistic & 1.1524 & 2.3263 & 1.6449 & 1.2816 \\
\hline \multicolumn{2}{|c|}{ Second Generation Panel Unit Root Tests: Full panel } \\
\hline Moon Perron1 statistic (ta_bar statistic) & $-10.7505^{* * *}$ & -2.3263 & -1.6449 & -1.2816 \\
\hline Moon Perron2 statistic (tb_bar statistic) & $-5.4646^{* * *}$ & -2.3263 & -1.6449 & -1.2816 \\
\hline Pesaran (2007) test statistic & -1.3881 & -2.7260 & -2.6077 & -2.5441 \\
\hline Choi test statistic $\left(\mathrm{P}_{\mathrm{m}}\right)$ & $6.6531^{* * *}$ & 2.3263 & 1.6449 & 1.2816 \\
\hline Choi test statistic $(Z)$ & $-5.6899^{* * *}$ & -2.3263 & -1.6449 & -1.2816 \\
\hline Choi test statistic $($ Lstar) & $-5.5484 * * *$ & -2.3263 & -1.6449 & -1.2816 \\
\hline
\end{tabular}

Table 6: Panel Unit Root Test Results with Structural Breaks ${ }^{11}$

\begin{tabular}{|c|c|c|c|c|}
\hline Panels & No break & One break & Two breaks \\
\hline Full Panel & \multicolumn{2}{|c|}{$-18.135 * * *$} & $-35.817 * * *$ & $-45.381 * * *$ \\
\hline & Note: The $1 \%, 5 \%$ and $10 \%$ critical values for the panel LM unit root tests with \\
& structural breaks are \\
& $-2.326,-1.645$ and -1.282 respectively. * Significance at $10 \%$ level. ** Significance \\
& at $5 \%$ level. *** Significance at $1 \%$ level. \\
\hline
\end{tabular}

As a starting point of panel stationarity analysis, we employ the first generation panel unit root tests which allow for cross-sectional independence between countries. As displayed in Table 5, the results suggest that the unemployment hysteresis null hypothesis cannot be rejected by all the first generation tests (LLC, IPS, MW and Choi tests). This finding of stationarity is not in line with Song and Wu (1998) who reported the absence of hysteresis in unemployment for the quarterly data of 15 countries by using Levin and

10 We can find Matlab codes for the Panel Unit Root test on Christophe Hurlin's homepage (http://www.univ-orleans.fr/deg/masters/ESA/CH/churlin_R.htm).

11 We can find Gauss codes for the Im, Lee and Tieslau (2005) test on Junsoo Lee's homepage (http://old.cba.ua.edu/ jlee/gauss). 
Lin (1992) panel unit root test. However, the cross-sectional (CD) dependence test rejects the presence of cross-sectional independence and hence, the first generation unit root test is not applicable. Therefore, the failure of the these tests to reject the null of unemployment hysteresis is due to the fact that the first generation panel unit root tests do not allow neither for cross-sectional dependence nor for possible structural breaks. In light of these considerations, when we consider the cross-sectional dependence test, our empirical findings show that the second generation panel unit root tests (except for Pesaran test) provide evidence that unemployment rate contains stationarity process. Thus, the consideration of cross-sectional assumption gives more consistent results and rejection of hysteresis hypothesis is obtained when cross-country interdependence in unemployment rates is incorporated. This study has applied the panel unit root test of Im, Lee and Tieslau (2005) which allows for structural breaks. This test improves largely the power of the panel unit root tests and increases the amount of information in panel data. The results reported in Table 6 support evidence of unemployment rate stationarity which confirm the finding of the second generation unit root tests. This result indicates that shocks to unemployment in OECD countries are temporary and the unemployment rate will revert back to its long-run trend. Hence, the failure to reject the unit root hypothesis of OECD unemployment rates is due to the lower power of classical unit root tests which do not take into account the cross-sectional and structural break assumptions.

\section{Conclusion and Policy Implications}

This study retests the unit root properties of unemployment rate by using the data of OECD countries for the period of 1980-2013 to confirm either unemployment hysteresis hypothesis exists or does not. In doing so, linear and non-linear unit root tests have been applied for testing the unit root properties. Further, cross-sectional dependence as well as panel unit root tests with and without structural breaks have also been applied. The empirical analysis reveals that unemployment rate contain stationary process almost in $86 \%$ of sampled countries that seems to reject the unemployment hysteresis hypothesis. The results of panel unit root tests also show the absence of unemployment hysteresis hypothesis in the presence of cross dependence and structural breaks. 
The empirical findings of the study suggest some fundamental policy implications. As the results support the non-existence of hysteresis hypothesis or stationary process, the process returns to the mean, while the mean moves over time. This indicates that shocks are transitory and produce simply impermanent changes of the unemployment rate nearby the equilibrium position. Hence, there is a resilient tendency for the unemployment rate to go back to its long-run equilibrium level following macroeconomic shocks in the OECD countries. Therefore, there is no need to execute costly macroeconomic stabilization policy, otherwise any fine-tuning is likely to disturb unemployment equilibrium level and thereby will bring macroeconomic instability instead of stability in these countries. Hence, unemployment rate in OECD countries is expected to return back to natural levels without the interferences from the OECD's governments.

The conclusion regarding the persistency of unemployment will of course depend on the flexibility of wages to attain the unemployment equilibrium levels without active public interventions in the labour market. Labour market is heavily regulated and job-market training and employment programs are natural elements of the state intervention policies. Given the alarming state of youth unemployment, mobility of capital, capital-labour substitution and technology's influence on relocation of production, it is not possible to think of a situation where state is not actively intervening to labour market. The suggested improved testing procedures, functional forms and accounting for crosssectional dependence and structural breaks will increase the power of the unit root tests and enable more accurate inference about state interventions in labour market.

\section{References}

Abadir, K. M. and Distaso, W. (2007). Testing joint hypotheses when one of the alternatives is one-sided. Journal of Econometrics, 140, 695-718.

Arestis, P. and Mariscal, I. (1999). Unit roots and structural breaks in OECD unemployment. Economics Letters, 65, 149-156.

Arestis, P. and Mariscal, I. (2000). OECD unemployment: structural breaks and stationary. Applied Economics, 32, 399-403. 
Blanchard, O. J. and Summers, L. H. (1986a). Hysteresis in unemployment problem. NBER Working Paper no. 2035.

Blanchard, O. J. and Summers, L. H. (1986b). Hysteresis and the European unemployment problem. NBER Working Paper no. 1950.

Bolat, A., Tiwari, A.K. and Erdayi, A.U. (2014) "Unemployment hysteresis in the Eurozone area: evidences from nonlinear heterogeneous panel unit root test", Applied Economics Letters, 21(8), 536-540.

Breuer, J.B., McNown, R., Wallace, M.S., 2001. Misleading inferences from panel unitroot tests with an illustration from purchasing power parity. Review of International Economics, 9 (3), 482-493.

Brunello, G. (1990). Hysteresis and the Japanese experience: A preliminary investigation. Oxford Economic Papers, 42, 483-500.

Camarero, M. and Tamarit, C. (2004). Hysteresis vs. natural rate of unemployment: new evidence for OECD countries. Economics Letters, 84, 413-417.

Camarero, M., Carrión-i-Silvestre, J. L. and Tamarit, C. (2006). Testing for hysteresis in unemployment in OECD countries. New evidence using stationarity panel tests with breaks. Oxford Bulletin of Economics and Statistics, 68, 167-182.

Cancelo, J.R. (2007). Cyclical asymmetries in unemployment rates: international evidence. International Advances in Economic Research, 13, 334-346.

Caner, M. and Hansen, B. E. (2001). Threshold autoregrssion with a unit root. Econometrica, 69, 1555-1596.

Chang, T., Nieh, K.C., Wei, C.C., 2005. An empirical note on testing hysteresis in unemployment for ten European countries: panel SURADF approach. Applied Economics Letters, 12, 881-886.

Chang, T. and Lee, C-H. (2011). Hysteresis in unemployment for G-7 countries: Threshold unit root test. Romanian Journal of Economic Forecasting, 4, 5-14.

Chang, H.-L., Liu, D.-C. and Su, C.-W. (2012). Purchasing power parity with flexible Fourier stationary test for Central and Eastern European countries. Applied Economics, 44, 4249-4256. 
Cheng, S-C., Wu, T., Lee, K-C. and Chang, T. (2014). Flexible Fourier unit root test of unemployment for PIIGS countries. Economic Modeling, 36, 142-148.

Choi, I. (2001). Unit root tests for panel data. Journal of International Money and Finance, 20, 249-272.

Choi, I. (2006).Nonstationary panels. In Palgrave Handbooks of Econometrics, Vol. 1, MillsTC, PattersonK (eds). Palgrave Macmillan. Basingstoke, 511-539.

Chou, H.C. and Zhang, Y.C. (2012). "Unemployment hysteresis in G20 countries: Evidence from non-linear panel unit-root tests", African Journal of Business Management, 6 (49), 11887-11890.

Christopoulos, D.K. and León-Ledesma, M.A. (2007). "Unemployment hysteresis in EU countries: what do we really know about it?", Journal of Economic Studies, 34(2): 80-89.

Clemente, J., Montanes, A. and Reyes, M. (1998). Testing for a unit root in variables with a double change in the mean. Economics Letters, 59, 175-182.

Elmskov, J. and MacFarlan, M. (1993). Unemployment persistence. OECD Economic Studies, 21, 60-89.

Enders, W. and Lee, J. (2012). A unit root test using a Fourier series to approximate smooth breaks. Oxford bulletin of Economics and Statistics, 74, 574-599.

Ener, M. and Arica, F. (2011). Is there hysteresis in unemployment in OECD countries? Evidence from panel unit root test with structural breaks. Chinese Business Review, 10, 294-304.

Everaert, G. (2001). Infrequent large shocks to unemployment: new evidence on alternative persistence perspectives. Labor, 15, 555-577.

Fève, P., Hènin, P.Y.and Jolivaldt, P. (1999). Testing for hysteresis: unemployment persistence and wage adjustment. Empirical Economics, 28, 535-552.

Figueiredo, E. A. (2010). Dynamics of regional unemployment rates in Brazil: Fractional behavior, structural breaks, and Markov switching. Economic Modelling, 27, 900908.

Fisher, R.A. (1932). Statistical methods for research workers. Fourth Edition, Edinburgh, Oliver and Boyd. 
Fosten, J. and Ghoshary, A. (2011). Dynamic persistence in the unemployment rate of OECD countries. Economic Modelling, 28, 948-954.

Frees, E. W. (1995). Assessing cross-sectional correlations in panel data. Journal of Econometrics, 69, 393-414.

Friedman, M. (1937). The use of ranks to avoid the assumption of normality implicit in the analysis of variance. Journal of the American Statistical Association, 32, 675-701.

Furuoka, F. (2014). Are unemployment rates stationary in Asia-Pacific countries? New findings from Fourier ADF test. Economic Research, 27, 34-45.

Galvao, Jr. A. F. (2009). Unit root quantile autoregrssion testing using covariates. Journal of Econometrics, 152, 165-176.

Gray, D., 2004. Persistent regional unemployment differentials revisited. Regional Studies, 38, 167-176.

Harris, D., McCabe, B. P. and Leybourne, S. J. (2003). Some limit theory for autocovariances whose order depends on sample size. Econometric Theory, 10, 829864.

Harvey D. I.and Leybourne. S. J. (2007). Testing for time series linearity. Econometrics Journal, 10, 149-65.

Harvey, D. I., Leybourne, S. J. and Xiao, B. (2008). A powerful test for linearity when the order of integration is unknown. Studies in Nonlinear Dynamics \& Econometrics, $12,1-24$.

Hayashi, N., 2005. Structure changes and unit roots in Japan's macroeconomic time series: is real business cycle theory supported. Japan and the World Economy, 17, $239-259$.

Huang, S-C. (2011). Testing for unit roots and persistence in EU unemployment rates. The Empirical Economics Letters, 10, 669-677.

Hurlin, C. (2004). Testing Granger causality in heterogeneous panel data models with fixed coefficients. Document de recherche LEO.

Im, K. S., Lee, J. and Tieslau, M. (2005). Panel LM unit root tests with level shifts. Oxford Bulletin of Economics and Statistics, 67, 393-419. 
Im, K.S., Pesaran, M. H. and Shin, Y. (2003). Testing for unit roots in heterogeneous panels. Journal of Econometrics, 115, 53-74.

Kapetanios, G., Shin, Y., Snell, A., 2003. Testing for a unit root in the non-linear STAR framework. Journal of Econometrics, 112, 359-379.

Kruse R., 2011. A new unit root test against ESTAR based on a class of modified statistics. Statistical Papers, 52, 71-85.

Lee, C-C. and Chang, C-P. (2008). Unemployment hysteresis in OECD countries: Centurial time series evidence with structural breaks. Economic Modelling, 25, 312325 .

Lee, C-F. (2010). Testing for unemployment hysteresis in nonlinear heterogeneous panels: International evidence. Economic Modelling, 27, 1097-1102.

Lee, C-F., Hu, T-C., Li, P-C. and Tsong, C-C. (2013). Asymmetric behavior of unemployment rates: evidence from the quantile covariate unit root test. Japan and the World Economy, 28, 72-84.

Lee, J. and Strazicich, M. (2003). Minimum Lagrange Multiplier unit root test with two structural breaks. Review of Economics and Statistics, 85(4), 1082-1089.

Lee, J. and Strazicich, M. (2004). Minimum LM unit root test with one structural break. Working Papers 04-17, Department of Economics, Appalachian State University.

Lee, J. and Strazicich, M. (2013). Minimum LM unit root test with two structural break. Economics Bulletin, 33, 2483-2492.

Lee, J-D., Lee, C-C. and Chang, C-P. (2009). Hysteresis in unemployment revisited: evidence from panel LM unit root tests with heterogeneous structural breaks. Bulletin of Economic Research, 61, 325-334.

Leon-Ledesma, M.A., McAdam, P. (2004). Unemployment, hysteresis and transition. Scottish Journal of Political Economy, 51 (3), 377-401.

Levin, A., Lin, C.F. and Chu, C.S.J. (2002). Unit root test in panel data: asymptotic and finite sample properties. Journal of Econometrics, 108, 1-24.

Leybourne, S., Kim, T. and Taylor, A. M. (2007). Detecting multiple changes in persistence. Studies in Nonlinear Dynamics and Economics, 11, 1-23. 
Liew, V, K-S., Chia, R. C-J. and Puah, C-H. (2012). Does hysteresis unemployment occur in OECD countries? Evidence from parametric and non-parametric panel unit root tests. International Journal of Economics and Management, 6(2), 446-458.

Lin, C.H., Kuo, N.F. and Yuan, C.D. (2008). "Nonlinear vs. nonstationary of hysteresis in unemployment: evidence from OECD economies", Applied Economics Letters, 15(11): 905-909.

Liu, D-C., Sun, C-H. and Lin, P-C. (2012). Hysteresis hypothesis in unemployment and labour force participation rates: evidence from Australian states and territories. Australian Economic Papers, 51, 71-84.

Maddala, G.S. and Wu, S. (1999). A comparative study of unit roots with panel data and a new simple test. Oxford Bulletin of Economics and Statistics, 61, 63-651.

Mitchell, W. F. (1993). Testing for unit roots and persistence in OECD unemployment rates. Applied Econometrics, 25, 1489-1501.

Moon, H. R. and Perron, B. (2004). Testing for a unit root in panels with dynamic factors. Journal of Econometrics, 122, 81-126.

Nybolm, J. and Harvey, A. (2000). Tests of common stochastic trends. Econometric Theory, 16, 176-199.

Papell, D.H., Murray, C.J., Ghiblawi, H., 2000. The structure of unemployment. The Review of Economics and Statistics, 82, 309-315.

Pesaran, M. H. (2004). General diagnostic tests for cross section dependence in panels. University of Cambridge, Faculty of Economics, Cambridge Working Papers in Economics No. 0435.

Pesaran, M. H. (2007). A simple panel unit root test in the presence of cross-section dependence. Journal of Applied Econometrics, 22, 265-312.

Røed, K. (1996). Unemployment hysteresis - Macro evidence from 16 OECD Countries. Empirical Economics, 21, 589-600.

Røed, K. (2002). Unemployment hysteresis and the natural rate of vacancies. Empirical Economics, 27, 687-704.

Smyth, R., 2003. Unemployment hysteresis in Australian states and territories: evidence from panel data unit root tests. The Australian Economic Review, 36, 181-192. 
Smyth, R., Inder, B., 2004. Is Chinese provincial real GDP per capita nonstationary? Evidence from multiple trend break unit root tests. China Economic Review 15, 1-24.

Song, F.M. and Wu, Y. (1998). Hysteresis in unemployment: evidence from OECD countries. The Quarterly Review of Economics and Finance, 38, 181-192.

Strazicich, M.C., Tieslau, M. and Lee, J. (2002). "Hysteresis in unemployment? Evidence from panel unit root test with structural change", University of North Texas Working Paper, No.01-08.

Tiwari, A. K. (2014). Unemployment hysteresis in Australia: Evidence using non-linear and stationarity test with breaks. Quality \& Quantity, 48, 681-695.

Ucar, N. and Omay, T. (2009). Testing for unit root in nonlinear heterogeneous panels. Economic Letters, 104, 5-8.

Yamamoto, T., 1996. A simple approach to the statistical inference in linear time series models which may have some unit roots. Hitotsubashi Journal of Economics, 37, 87100.

Yilanci, V. (2008). Are unemployment rates nonstationary or nonlinear? Evidence from 19 OECD countries. Economics Bulletin, 3, 1-5.

Yoon, G. (2009). It's all the minors' fault: On the nonlinearity in U.S. unemployment rates. Economic Modelling, 26, 1449-1454. 


\section{Appendix}

Appendix A: Summary of Literature on Hypothesis of Hysteresis in Unemployment

\begin{tabular}{|c|c|c|c|c|c|c|c|c|c|}
\hline Author(s) & Countries & Period & Empirical Method & $\begin{array}{l}\text { Linear } \\
\text { unit root } \\
\text { test }\end{array}$ & $\begin{array}{l}\text { Nonlinear } \\
\text { unit root } \\
\text { test }\end{array}$ & $\begin{array}{l}\text { Structur } \\
\text { al } \\
\text { breaks }\end{array}$ & $\begin{array}{l}\text { Functional } \\
\text { form }\end{array}$ & $\begin{array}{l}\text { Regime } \\
\text { switchin } \\
\text { g }\end{array}$ & Hysteresis hypothesis \\
\hline $\begin{array}{l}\text { Blanchard and } \\
\text { Summers (1986) }\end{array}$ & $\begin{array}{l}\text { France, } \\
\text { Germany, } \\
\text { UK and U.S. }\end{array}$ & $1953-1984$ & $\begin{array}{l}\mathrm{DF} \text { and } \mathrm{ADF} \\
\text { unit root tests }\end{array}$ & Yes & No & No & Linear & No & $\begin{array}{l}\text { No: U.S. Yes: France, } \\
\text { Germany, UK }\end{array}$ \\
\hline Brunello (1990) & Japan & $1955-1987$ & DF unit root & Yes & No & No & Linear & No & Yes \\
\hline Mitchell (1993) & $\begin{array}{l}15 \text { OECD } \\
\text { countries }\end{array}$ & $\begin{array}{l}1960 Q_{1}- \\
1991 Q_{3} \\
\end{array}$ & PP test & Yes & No & No & Linear & No & Yes \\
\hline Røed (1996) & $\begin{array}{l}16 \text { OECD } \\
\text { countries }\end{array}$ & $\begin{array}{l}\text { 1970Q1- } \\
\text { 1994Q4 }\end{array}$ & $\begin{array}{l}\text { Exact maximum } \\
\text { likelihood } \\
\text { stationarity test }\end{array}$ & Yes & No & No & Linear & No & No for US \\
\hline $\begin{array}{l}\text { Song and } \mathrm{Wu} \\
\text { (1998) }\end{array}$ & $\begin{array}{l}15 \text { OECD } \\
\text { countries }\end{array}$ & $\begin{array}{l}1972 Q_{1-} \\
1992 Q_{2}\end{array}$ & Panel unit root test & Yes & No & No & Linear & No & No \\
\hline $\begin{array}{l}\text { Papell et al. } \\
(2000)\end{array}$ & $\begin{array}{l}16 \text { OECD } \\
\text { countries }\end{array}$ & $1955-1997$ & $\begin{array}{l}\text { Zivot and Andrews } \\
\text { Unit root (one } \\
\text { structural break) }\end{array}$ & $\begin{array}{l}\text { Yes (Linear } \\
\text { unit root } \\
\text { test with } \\
\text { structural } \\
\text { break) }\end{array}$ & No & Yes & $\begin{array}{l}\text { Linear } \\
\text { regression }\end{array}$ & No & $\begin{array}{l}\text { No: Belgium, Canada, } \\
\text { Denmark, Finland, Ireland, } \\
\text { Norway, Sweden, Spain, U.S., } \\
\text { UK }\end{array}$ \\
\hline $\begin{array}{l}\text { Arestis and } \\
\text { Mariscal } \\
(2000)\end{array}$ & $\begin{array}{l}22 \text { OECD } \\
\text { countries }\end{array}$ & $\begin{array}{l}1960 Q_{1-}^{-} \\
\text {1997Q }_{2}\end{array}$ & $\begin{array}{l}\text { Perron's (1997) unit } \\
\text { root test }\end{array}$ & Yes & No & Yes & Linear & No & $\begin{array}{l}\text { No: Australia, Belgium, } \\
\text { Canada, } \\
\text { Denmark, Finland, Germany, } \\
\text { Luxembourg, Switzerland and } \\
\text { the UK }\end{array}$ \\
\hline Everaert (2001) & $\begin{array}{l}21 \text { OECD } \\
\text { countries }\end{array}$ & 1960-1999 & $\begin{array}{l}\text { Tsay's (1988) } \\
\text { intervention model }\end{array}$ & Yes & No & No & Linear & No & No \\
\hline $\begin{array}{l}\text { Strazicich et al. } \\
\text { (2002) }\end{array}$ & $\begin{array}{l}\text { France, } \\
\text { Germany, } \\
\text { Italy, Spain } \\
\text { and } \\
\text { UK }\end{array}$ & 1955-1999 & $\begin{array}{l}\text { - LM Test } \\
\text { - LM test with } \\
\text { structural breaks }\end{array}$ & Yes & No & Yes & Linear & No & Yes \\
\hline Røed (2002) & $\begin{array}{l}10 \text { OECD } \\
\text { countries }\end{array}$ & $1960-1995$ & $\begin{array}{l}\text { ADF and KPSS } \\
\text { unit root tests }\end{array}$ & Yes & No & No & Linear & No & No: US \\
\hline $\begin{array}{l}\text { Fève et al. } \\
(2003)\end{array}$ & $\begin{array}{l}21 \text { OECD } \\
\text { countries }\end{array}$ & $\begin{array}{l}1966 Q_{1-} \\
1999 Q_{1}\end{array}$ & $\begin{array}{l}A D F, \text { KPSS and } \\
\text { generalization of } \\
A D F\end{array}$ & Yes & No & No & Linear & No & $\begin{array}{l}\text { No: Australia, Belgium, } \\
\text { Canada, Denmark, Finland, } \\
\text { Netherlands, Norway, U.S. }\end{array}$ \\
\hline
\end{tabular}




\begin{tabular}{|c|c|c|c|c|c|c|c|c|c|}
\hline Smyth (2003) & $\begin{array}{l}\text { Australian } \\
\text { States }\end{array}$ & $\begin{array}{l}1983 Q_{2-} \\
2002 Q_{1}\end{array}$ & $\begin{array}{l}\text { LL and IPS unit root } \\
\text { tests }\end{array}$ & Yes & No & No & Linear & No & Yes \\
\hline $\begin{array}{l}\text { Camarero and } \\
\text { Tamarit (2004) }\end{array}$ & $\begin{array}{l}19 \text { OECD } \\
\text { countries }\end{array}$ & $1956-2001$ & $\begin{array}{l}\text { Multivariate SURE } \\
\text { unit root tests }\end{array}$ & Yes & No & No & Linear & No & $\begin{array}{l}\text { Yes: Austria, Germany, Italy, } \\
\text { Japan, } \\
\text { Norway, New Zealand and } \\
\text { Switzerland. }\end{array}$ \\
\hline $\begin{array}{l}\text { Leon-Ledesma } \\
\text { and } \\
\text { McAdam (2004) }\end{array}$ & $\begin{array}{l}12 \text { Central and } \\
\text { Eastern } \\
\text { European } \\
\text { Countries } \\
\text { and } 15 \mathrm{EU}\end{array}$ & $\begin{array}{l}1991 \mathrm{M}_{1-} \\
2001 \mathrm{M}_{5}\end{array}$ & $\begin{array}{l}\text { Univariate and } \\
\text { panel } \\
\text { unit root tests with } \\
\text { and } \\
\text { without breaks }\end{array}$ & Yes & No & Yes & Linear & No & No \\
\hline Gray (2004) & UK & $\begin{array}{l}1974 \mathrm{M}_{4-} \\
2002 \mathrm{M}_{12}\end{array}$ & $\begin{array}{l}\text { ADF and KPSS unit } \\
\text { root tests }\end{array}$ & Yes & No & No & Linear & No & Yes \\
\hline $\begin{array}{l}\text { Chang et al. } \\
(2005)\end{array}$ & $\begin{array}{l}10 \text { European } \\
\text { countries }\end{array}$ & 1961-1999 & $\begin{array}{l}\text { Panel SURADF unit } \\
\text { root tests (Breuer et } \\
\text { al., 2001) }\end{array}$ & Yes & No & No & Linear & No & $\begin{array}{l}\text { No: Belgium and the } \\
\text { Netherlands. }\end{array}$ \\
\hline Hayashi (2005) & Japan & $\begin{array}{l}1955 Q_{1-} \\
1998 Q_{2}\end{array}$ & $\begin{array}{l}\text { Augmented step- } \\
\text { wise } \\
\text { Chow test } \\
\text { (Yamamoto ,1996) }\end{array}$ & Yes & No & No & Linear & No & No \\
\hline $\begin{array}{l}\text { Camarero et al. } \\
\text { (2006) }\end{array}$ & $\begin{array}{l}19 \text { OECD } \\
\text { Countries }\end{array}$ & $1956-2001$ & $\begin{array}{l}\text { KPSS unit root test } \\
\text { with structural } \\
\text { breaks }\end{array}$ & Yes & No & Yes & Linear & No & No: France and UK. \\
\hline $\begin{array}{l}\text { Christopoulos, } \\
\text { and León- } \\
\text { Ledesma (2007) }\end{array}$ & $\begin{array}{l}12 \text { European } \\
\text { Union (EU) } \\
\text { countries }\end{array}$ & $\begin{array}{l}1988 Q_{1}-1999 \\
Q_{4}\end{array}$ & $\begin{array}{l}\text { The } \\
\text { second-generation } \\
\text { panel unit root tests }\end{array}$ & Yes & No & No & Linear & No & No \\
\hline Yilanci (2008) & $\begin{array}{l}19 \text { OECD } \\
\text { Countries }\end{array}$ & $\begin{array}{l}\text { Different } \\
\text { periods }\end{array}$ & $\begin{array}{l}\text { Nonlinear unit root } \\
\text { test (KSS) }\end{array}$ & No & Yes & No & Nonlinear & No & $\begin{array}{l}\text { No: Belgium, Czech Republic, } \\
\text { Korea, Netherlands, Poland, } \\
\text { Switzerland and USA. }\end{array}$ \\
\hline $\begin{array}{l}\text { Lee and Chang } \\
\text { (2008). }\end{array}$ & $\begin{array}{l}14 \text { OECD } \\
\text { countries }\end{array}$ & $\begin{array}{l}\text { Different } \\
\text { period samples }\end{array}$ & $\begin{array}{l}\text { LM unit root tests } \\
\text { without and with } \\
\text { structural breaks }\end{array}$ & Yes & No & Yes & Linear & No & No \\
\hline Lin et al. (2008) & $\begin{array}{l}16 \text { OECD } \\
\text { countries }\end{array}$ & $\begin{array}{l}1970 \mathrm{M}_{1-} \\
2005 \mathrm{M}_{4}\end{array}$ & $\begin{array}{l}\text { Threshold } \\
\text { autoregression } \\
\text { (TAR) test }\end{array}$ & No & Yes & No & Nonlinear & No & $\begin{array}{l}\text { Yes: Australia, Finland, France, } \\
\text { Germany, Japan and the USA }\end{array}$ \\
\hline Lee et al. (2009) & $\begin{array}{l}19 \text { OECD } \\
\text { countries }\end{array}$ & 1960-2004 & $\begin{array}{l}\text { The panel LM unit } \\
\text { root tests with } \\
\text { heterogeneous } \\
\text { structural breaks }\end{array}$ & Yes & No & Yes & Linear & No & No \\
\hline Chang (2011) & $\begin{array}{l}17 \text { OECD } \\
\text { countries }\end{array}$ & $1960-2009$ & $\begin{array}{l}\text { Stationary test with } \\
\text { a Fourier function }\end{array}$ & No & Yes & No & Nonlinear & No & $\begin{array}{l}\text { No: Australia, Canada, Finland, } \\
\text { France, Sweden and the US. }\end{array}$ \\
\hline
\end{tabular}




\begin{tabular}{|c|c|c|c|c|c|c|c|c|c|}
\hline $\begin{array}{l}\text { Chou and Zhang } \\
\text { (2012) }\end{array}$ & G20 countries & $1980-2008$ & $\begin{array}{l}\text { SURADF and } \\
\text { SURKSS tests }\end{array}$ & Yes & No & No & Linear & No & $\begin{array}{l}\text { No: Belgium, Canada, } \\
\text { Denmark, Finland, France, } \\
\text { Germany, New Zealand, } \\
\text { Norway and Portugal }\end{array}$ \\
\hline $\begin{array}{l}\text { Chang and Su } \\
\text { (2014) }\end{array}$ & Taiwan & $\begin{array}{l}\text { Six educational } \\
\text { attainment } \\
\text { categories, } \\
\text { between } \\
\text { January } 1978 \\
\text { and June } 2012 \text {. }\end{array}$ & $\begin{array}{l}\text { First and second } \\
\text { generations panel } \\
\text { unit root test }+ \\
\text { Carrion-i-Sylvester } \\
\text { et al. panel unit root } \\
(2005)+\text { KSS unit } \\
\text { root test }\end{array}$ & Yes & Yes & Yes & $\begin{array}{l}\text { Linear and } \\
\text { Nonlinear }\end{array}$ & No & No: junior college graduates \\
\hline $\begin{array}{l}\text { Bolat et al. } \\
\text { (2014) }\end{array}$ & $\begin{array}{l}17 \mathrm{EU} \\
\text { countries }\end{array}$ & 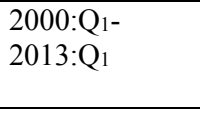 & $\begin{array}{l}\text { Nonlinear panel unit } \\
\text { root tests }\end{array}$ & No & Yes & No & Nonlinear & No & $\begin{array}{l}\text { Yes: Netherlands, Slovakia, } \\
\text { Slovenia, Italy, Portugal and } \\
\text { Cyprus. }\end{array}$ \\
\hline Tiwari (2014). & Australia & $\begin{array}{l}1978 \mathrm{M}_{2-} \\
2010 \mathrm{M}_{12}\end{array}$ & $\begin{array}{l}\text { Linear and } \\
\text { Nonlinear unit root } \\
\text { tests }\end{array}$ & Yes & Yes & Yes & $\begin{array}{l}\text { Linear and } \\
\text { Nonlinear }\end{array}$ & No & Yes \\
\hline
\end{tabular}




\section{Appendix B: Descriptive statistics on unemployment rates}

\begin{tabular}{|c|c|c|c|c|c|c|c|c|c|}
\hline Country & Mean & Median & $\begin{array}{l}\text { Maxi- } \\
\text { mum }\end{array}$ & $\begin{array}{l}\text { Mini- } \\
\text { mum }\end{array}$ & $\begin{array}{r}\text { Std. } \\
\text { Dev. }\end{array}$ & $\begin{array}{r}\text { Skew- } \\
\text { ness }\end{array}$ & Kurtosis & $\begin{array}{r}\text { Jarque- } \\
\text { Bera } \\
\end{array}$ & $\begin{array}{r}\text { Proba- } \\
\text { bility }\end{array}$ \\
\hline Australia & 7.0512 & 6.8460 & 10.9000 & 4.2750 & 1.8539 & 0.4511 & 2.2114 & 2.0341 & 0.3617 \\
\hline Austria & 3.7972 & 3.8835 & 5.2000 & 1.6000 & 0.8218 & -0.7361 & 3.1868 & 3.1201 & 0.2101 \\
\hline Belgium & 8.5219 & 8.3540 & 11.5000 & 6.4420 & 1.3448 & 0.3128 & 2.1996 & 1.4622 & 0.4814 \\
\hline Canada & 8.5089 & 7.8835 & 11.9250 & 6.0580 & 1.6769 & 0.5487 & 2.1037 & 2.8440 & 0.2412 \\
\hline Chile & 9.6882 & 8.7585 & 20.9990 & 6.1080 & 3.6886 & 1.7209 & 5.4777 & 25.4788 & 0.0000 \\
\hline Denmark & 6.2163 & 6.1915 & 9.5330 & 3.4750 & 1.5575 & 0.0950 & 2.0105 & 1.4381 & 0.4872 \\
\hline Finland & 8.3261 & 7.9180 & 16.6060 & 3.2000 & 3.5926 & 0.8312 & 2.9686 & 3.9162 & 0.1411 \\
\hline France & 9.6148 & 9.5670 & 11.6830 & 6.3490 & 1.2542 & -0.3429 & 2.9113 & 0.6775 & 0.7127 \\
\hline Germany & 7.7463 & 7.8630 & 11.2080 & 3.3590 & 1.6874 & -0.3383 & 3.1577 & 0.6836 & 0.7105 \\
\hline Greece & 9.8627 & 9.1850 & 26.9860 & 2.6630 & 4.7682 & 2.1674 & 8.2626 & 65.8533 & 0.0000 \\
\hline Hungary & 5.8854 & 6.8000 & 11.2900 & 0.0410 & 4.1579 & -0.3208 & 1.5729 & 3.4682 & 0.1766 \\
\hline Iceland & 2.7489 & 1.8210 & 8.1320 & 0.3130 & 2.2264 & 1.0376 & 3.1346 & 6.1261 & 0.0467 \\
\hline Ireland & 11.5706 & 12.9310 & 19.0000 & 3.9300 & 5.3420 & -0.1906 & 1.5175 & 3.3192 & 0.1902 \\
\hline Israel & 8.6727 & 8.6030 & 13.4000 & 4.5620 & 2.4794 & 0.1131 & 2.0053 & 1.4742 & 0.4785 \\
\hline Italy & 8.9994 & 8.7080 & 12.0420 & 6.1000 & 1.5046 & 0.2315 & 2.1881 & 1.2374 & 0.5386 \\
\hline Japan & 3.5252 & 3.3705 & 5.3580 & 2.0220 & 1.1050 & 0.1566 & 1.5477 & 3.1269 & 0.2094 \\
\hline Korea & 3.5573 & 3.4375 & 6.9500 & 2.0580 & 1.0938 & 1.3677 & 5.3174 & 18.2079 & 0.0001 \\
\hline Luxembourg & 2.9023 & 2.6160 & 6.2960 & 0.7230 & 1.5777 & 0.7051 & 2.4250 & 3.2861 & 0.1934 \\
\hline Mexico & 3.8031 & 3.7080 & 6.2300 & 0.9000 & 1.2710 & -0.0657 & 2.7832 & 0.0910 & 0.9555 \\
\hline The Netherlands & 5.1351 & 5.1000 & 8.2540 & 2.5410 & 1.4734 & 0.2319 & 2.3432 & 0.9157 & 0.6326 \\
\hline New Zealand & 6.0644 & 6.1955 & 10.6250 & 3.6750 & 1.9344 & 0.7073 & 2.9463 & 2.8390 & 0.2418 \\
\hline Norway & 3.6744 & 3.4260 & 5.9480 & 1.6500 & 1.1669 & 0.3182 & 2.2054 & 1.4684 & 0.4799 \\
\hline Portugal & 7.5469 & 7.2255 & 18.2500 & 3.8600 & 3.1841 & 1.5788 & 5.8865 & 25.9288 & 0.0000 \\
\hline Spain & 17.1007 & 17.6200 & 27.0000 & 8.2750 & 5.0921 & -0.1224 & 2.0172 & 1.4534 & 0.4835 \\
\hline Sweden & 5.6762 & 5.8670 & 9.8830 & 1.5580 & 2.6650 & -0.0867 & 1.6332 & 2.6891 & 0.2607 \\
\hline Switzerland & 2.2253 & 2.3810 & 4.5050 & 0.1810 & 1.3626 & -0.0938 & 1.5693 & 2.9496 & 0.2288 \\
\hline Turkey & 8.7339 & 8.4105 & 14.0280 & 6.4970 & 1.6921 & 1.0224 & 4.0232 & 7.4070 & 0.0246 \\
\hline United Kingdom & 7.8518 & 7.8395 & 11.7770 & 4.7880 & 2.1964 & 0.2433 & 1.8589 & 2.1799 & 0.3362 \\
\hline United States & 6.4746 & 6.0460 & 9.7080 & 3.9670 & 1.6523 & 0.5246 & 2.2830 & 2.2879 & 0.3186 \\
\hline
\end{tabular}

